\title{
Multidisciplinary studies of global Carboniferous stage boundaries: towards a better definition and global correlations: an introduction
}

\author{
ZHONG-QIANG CHEN*†, XIANGDONG WANG \\ \& MARKUS ARETZ \\ * State Key Laboratory of Biogeology and Environmental Geology, China University of Geosciences (Wuhan), \\ Wuhan 430074, China \\ $\ddagger$ State Key Laboratory of Paleobiology and Stratigraphy, Nanjing Institute of Geology and Palaeontology, \\ Chinese Academy of Sciences, Nanjing 21008, China \\ $\S$ Geological Survey of Canada, Calgary AB T2L 2A7, Canada \\ ףUniversité de Toulouse (UPS), GET (OMP), 14 avenue E. Belin, 31400 Toulouse, France
}

Earth was very dynamic during the Carboniferous with major components of the Pangea supercontinent being assembled from late Famennian to latest Pennsylvanian times, although maximum consolidation occurred during Late Permian - Early Triassic time. During the Carboniferous Period, our planet also underwent at least three major icehouse periods. The first two, in late Famennian - early Tournaisian and late Visean Bashkirian times, indicate the onset of the Late Palaeozoic Ice Age (LPIA) with ice sheets being confined to the alpine regions of southern Gondwana. The third icehouse regime during Gzhelian - Early Permian time represents the main episode of the LPIA when a continental ice sheet developed on the Australian, Antarctic and southern African components of southern Gondwana. During the Tournaisian equatorial areas in Euramerica were occupied by extensive arid belts, in which massive carbonate deposits formed on vast platforms in that time. From the late Tournaisian into the Visean and Serpukhovian much of the equatorial belt developed into a humid-tropical realm and the former arid belt split and shifted to higher latitudes. Shelfcarbonate deposition continued over extensive areas of the continental shelves and western Palaeo-Tethys but coal swamps were developing in the forelands of the rising Appalachian and Variscan orogens. The late Serpukhovian - early Bashkirian interval saw the closure of the Rheic Ocean and a continent-continent collision between Euramerica (Laurussia) and Gondwana to form Pangea. As a consequence, a marked transition from Visean carbonate deposition to the development of coal swamps and deposition of siliciclastics during the Serpukhovian Stage occurred in many regions.

†Author for correspondence: zhong.qiang.chen@uwa.edu.au; zqchen.uwa@gmail.com
Marine biotas have suffered two second-order mass extinctions, namely the latest Famennian/Hangenberg and mid-Carboniferous mass extinctions (Bambach, 2006). In contrast, the Tournaisian - Visean interval also saw biotic radiation/recovery from the Late Devonian mass extinctions in the sea; maximum diversity was found during late Visean time. Most reef-forming organisms became extinct during the Late Devonian. Waulsortian, stromatolitic, and thrombolitic carbonate mounds dominated the reef and mound settings during most of the Mississippian but a diversity of buildups including those constructed by Palaeoaplysina, phylloid algae, and aragonitic radial-fibrous cements developed in the Late Mississippian and Pennsylvanian.

Terrestrial ecosystems were characterized by the pronounced diversification of terrestrial plants, the establishment of vast lowland forests (coal swamps) in lowto medium-latitude regions and the evolution of reptiles from amphibians in the late Mississippian and Pennsylvanian. In particular, terrestrial plants colonized extensive low-lying non-marine settings during Late Devonian time. Forests became much more extensive throughout the Carboniferous Period when terrestrial floras were dominated by plants that reproduced by spores (sphenopsids, pteropsids and lycopsids) and were characterized by the common presence of seed ferns and the establishment of seed-bearing gymnosperms upland forests.

Accordingly, the Carboniferous Period was critical for the evolution of Earth life and formation of the Pangea supercontinent. Few stage boundaries of the Carboniferous have been precisely defined however, although the biostratigraphy of this period has been studied since the late nineteen century. To date, only the Global Stratotype Section and Points (GSSPs) of the Devonian-Carboniferous (D$\mathrm{C} ;$ = Famennian-Tournaisian), Tournaisian-Visean 
and mid-Carboniferous (= Serpukhovian-Bashikirian) boundaries have been established at the La Serre section of the Montagne Noire of SE France, the Pengchong section, Guangxi, South China and the Arrow canyon section, Nevada, USA, respectively.

In July 2011, more than 200 geoscientists assembled in Perth to present their new research results focusing on all aspects of Carboniferous-Permian geology, palaeontology and palaeoclimatology at the XVII International Congress on Carboniferous and Permian (ICCP 2011). From the papers presented at this conference, we selected eight papers addressing multidisciplinary studies on the stage boundaries within the Carboniferous for this special issue of Geological Magazine.

Recent studies show that an evolutionary lineage of key conodont species previously defining the DC boundary is absent from the GSSP La Serre (Kaiser, 2009). The D-C boundary (also the base of the Tournaisian) therefore requires a re-definition (Aretz, 2011). Here, Kumpan et al. (2014) documented a highresolution multiproxy stratigraphic analysis of the D-C boundary sections from the Czech Republic and attempted to correlate them with the same boundary successions worldwide. To provide a better definition of the D-C boundary in conodont-barren facies successions, Mottequin et al. (2014) recommended several shallowwater facies brachiopod species as the markers defining this boundary, based on intercontinental correlations of those brachiopod elements. Belgium records one of the most complete Early Carboniferous successions in the world. Poty et al. (2014) presented their detailed definitions of the stage and substage boundaries of both the Tournaisian and Visean based on Belgian stratigraphic records and suggested that those Belgian substage boundaries can be a basis for an international chronostratigraphic division of those two stages, which are unusually long.

Both Sevastopulo \& Barham (2014) and Qi et al. (2014a) documented detailed conodont zones defining the base of the Serpukhovian based on fossil records from NW Europe and South China, respectively. Those two studies provide the most up-to-date biostratigraphic correlations for the basal boundary of the Serpkhovian Stage. Kulagina et al. (2014) documented the detailed biostragraphic and lithostratigraphic changes across the mid-Carboniferous boundary from southern Urals, Russia, which provide a better understanding of the mid-Carboniferous boundary mass extinction and associated climate change and environmental stress. Sungatullina (2014) described conodont faunas and index zones across the Bashkirian-Moscovian boundary from the Volga region, Russia. Qi et al. (2014b) reported complete Carboniferous conodont zones from the southern Guizhou area, South China with emphasis on the definition of the Pennsylvanian (Late Carboniferous) stage boundaries.

Such a special issue on Carboniferous biostratigraphy is timely given the growing research interest in
Carboniferous palaeoclimate and life evolution which, however, lacks a fine timescale. Accordingly, we hope that this special issue of Geological Magazine will provide some new insights into the establishment of GSSPs of stage boundaries and a fine timescale of the Carboniferous Period.

Acknowledgements. We are grateful to all reviewers, M. Aretz, A. Balinski, Z.Q. Chen, J. Groves, S. Nikolaeva, E. Poty, Y.P. Qi, B. Richards, J. Sans-Lopez, G. Sevastopulo, Y.L. Sun and X.D. Wang, for their critical reviews of the papers collected in this thematic issue. ZQC's work is supported by the 973 Program of China (2011CB808800), the 111 Program of China (B08030) and research grants from both SKLGPMR and SKLBGEG (GPMR201302 and GBL11206).

\section{References}

ARETZ, M. 2011. Report on the workshop of the task group for defining the Devonian-Carboniferous boundary. Subcommission on Devonian Stratigraphy Newsletter 26, 18-20.

BAMBACH, R.K. 2006. Phanerozoic biodiversity and mass extinctions. Annual Review of Earth and Planetary Sciences 34, 127-55.

KAISER, S.I. 2009. The Devonian/Carboniferous boundary stratotype section (La Serre, France) revisited. Newsletters on Stratigraphy 43, 195-205.

Kulagina, E., Nikolaeva, S., PaZukhin, V. \& Kochetova, N. 2014. Biostratigraphy and lithostratigraphy of the Mid-Carboniferous boundary beds in the Muradymovo section (South Urals, Russia). Geological Magazine 151(2), 269-98.

KumPan, T., BÁBEK, O., KALVODA, J., FrÝDA, J. \& GRYGAR, T.M. 2014. A high-resolution, multiproxy stratigraphic analysis of the Devonian-Carboniferous boundary sections in the Moravian Karst (Czech Republic) and a correlation with the Carnic Alps (Austria). Geological Magazine 151(2), 201-15.

Mottequin, B., Brice, D. \& Legrand-Blain, M. 2014. Biostratigraphic significance of brachiopods near the Devonian-Carboniferous boundary. Geological Magazine 151(2), 216-28.

Poty, E., ARETZ, M. \& HANCE, L. 2014. Belgian substages as a basis for an international chronostratigraphic division of the Tournaisian and Viséan. Geological Magazine 151(2), 229-43.

QI, Y., Nemyrovska, T.I., Wang, X., Chen, J., WANG, Z., LANe, H.R., Richards, B.C., Hu, K. \& WANG, Q. 2014a. Late Visean - early Serpukhovian conodont succession at the Naqing (Nashui) section in Guizhou, South China. Geological Magazine 151(2), 254-68.

QI, Y., HU, K., WANG, Q. \& LIN, W. 2014b. Carboniferous conodont biostratigraphy of the Dianzishang section, Zhenning, Guizhou, South China. Geological Magazine 151(2), 311-27.

SeVAstopulo, G.D. \& BARHAM, M. 2014. Correlation of the base of the Serpukhovian Stage (Mississippian) in NW Europe. Geological Magazine 151(2), 244-53.

SungatullinA, G. 2014. Determination of the BashkirianMoscovian boundary in the Volga region via conodont species Declinognathodus donetzianus Nemirovskaya. Geological Magazine 151(2), 299-310. 